\title{
Empirical Study: Do Fund Managers Herd to Counter Investor Sentiment?
}

\author{
Tsai-Ling Liao ${ }^{1}$, Chih-Jen Huang ${ }^{1}$ and Chieh-Yuan $\mathrm{Wu}^{2}$ \\ 1 Providence University, Taichung, \\ ${ }^{2}$ Department of the Treasury Taichung Bank,
}

Taiwan

\section{Introduction}

Behavior among investors often influences one another. Investors may forego their own rational analysis but instead adopt behavior that is similar to the group. Recently, several studies note that this herding phenomenon (simultaneously trade the same stocks in the same direction) even exists in the behavior of institutional investors (Choe, Kho, and Stulz, 1999; Grinblatt, Titman, and Wermers, 1995; Kyrolainen and Perttunen, 2003; Lakonishok, Shleifer, and Vishny, 1992; Walter and Weber, 2006; Wermers, 1999; Wylie, 2005). There are three theoretical foundations for explaining institutional investor herding. First, in order to maintain or build a reputation when markets are imperfectly informed, managers may ignore their private information and hide in the herd (Brandenburger and Polak, 1996; Prendergast, 1993; Scharfstein and Stein, 1990; Trueman, 1994; Zwiebel, 1995). Second, managers may infer private information from the prior actions of agents (peer-group effects), and optimally decide to act alike (Bala and Goyal, 1998; Fung and Hsieh, 1999; Pound and Shiller, 1989). Third, institutional investors may receive the correlative private information from analyzing the same indicators (Banerjee, 1992; Bikhchandani, Hirshleifer, and Welch, 1992; Block, French, and Maberly, 2000; Froot, Scharfstein, and Stein, 1992; Hirshleifer, Subrahmanyam, and Titman, 1994) or favoring securities with specific characteristics (Del Guercio, 1996; Falkenstein, 1996; Gompers and Metrick, 2001; Payne, Prather, and Bertin, 1999).

What are the other factors that may explain the behavior of institutional investors herding? Investor sentiment may be one of the significant factors that cause this behavior. For example, Lakonishok et al. (1992, p.26) state in their pioneer research that, “...they (fund managers) might herd if they all counter the same irrational moves in individual investor sentiment." Barberis and Shleifer (2003), De Long et al. (1990), Lee et al. (1991), and Shleifer (2000) also make similar statements. Accordingly, one may intuitively expect that institutional investors will herd in their sell (buy) decisions in the presence of optimistic (pessimistic) sentiment. However, the literature appears to include no research that conducts an empirical investigation on this interesting hypothesis. The purpose of this study is thus to examine whether prior investor sentiment cross-sectionally explains the level of fund manager herding. 
This study focuses on the U.S. fund trading sample because herd behavior becomes increasingly important when large institutional investors dominate the market such as in the U.S. To estimate herding by fund managers, the study in this report applies the Lakonishok et al.'s (1992) measure and Wylie's (2005) trinomial-distribution approach which considers buy, hold and sell positions for a given stock in a period. The study calculates conditional herding measures for stock-months that have a higher or lower proportion of fund buyers relative to the expected proportion in each month, which are the buy-herding measure and the sell-herding measure. To estimate investor sentiment for each stock-month, this paper employs the principal component analysis as the means of extracting the composite unobserved sentiment measure, rather than just selects a single indicator to proxy sentiment (Fisher and Statman, 2000; Neal and Wheatley, 1998). Brown and Cliff (2004) indicate that this estimating procedure is able to successfully extract measures of unobserved sentiment from various indicators. According to Baker and Stein (2004), Brown and Cliff (2004) and Baker and Wurgler (2006), the present study examines ten market weather vanes that can be categorized into three groups: individual stock sentiment indicator (individual stock return and individual stock trading volume), overall market sentiment indicator (S\&P500 index return, S\&P500 index trading volume, S\&P500 index option Put/Call ratio, the number of IPOs, the average first-day return on IPOs, NYSE share turnover, and Russell 2000 index return), and fund sentiment indicator (net purchases of mutual funds).

After excluding observations with incomplete data to estimate herding, the final sample contains 770 U.S. mutual funds' holding records on 527 stocks from January 2001 to December 2005. Incorporating both bear (roughly 2001-2002) and bull (roughly 2003-2005) market periods under examination helps control for the effect of market conditions on the empirical results. The findings indicate a significantly positive association between the sentiment measure and subsequent sell-herding, after controlling the fund performance deviation, the capitalization of the stock, the number of funds trading the stock, the net mutual fund redemption of the stock, and the market-to-book ratio of the stock. However, the evidence shows no significant correlation between the composite sentiment measure and subsequent buy-herding. These findings suggest that institutional investors herd on the selling side when they observe high level of investor optimism, consistent with the intuition that rational institutional investors tend to counteract the optimistic sentiment of the investors (Wermers, 1999).

In sum, this paper contributes to the literature in three ways. First, by extending prior research that examines the impacts of fund herding on subsequent stock returns (Grinblatt et al., 1995; Klemkosky, 1977; Wermers, 1999), and the short-run predictability of sentiment in stock returns (Baker and Wurgler, 2006; Brown and Cliff, 2004; Fisher and Statman, 2000), this article substantiates the sentiment countering hypothesis and thereby contributes to the research realm of negative-feedback strategies, i.e. selling stocks that rise too far (Jegadeesh and Titman, 1993; Nofsinger and Sias, 1999; Scharfstein and Stein, 1990; Wermers, 1997, 1999). Second, the empirical finding indicates an explanatory power of investor sentiment for fund manager herding, providing support for the informational cascade theory where fund managers herd as a result of analyzing the sentiment indicator in this case. In other words, fund managers herd sell because, at least in part, they observe and try to counteract the optimistic sentiment. Finally, the significant association between sentiment and fund manager herding suggests potential directions for further research; specifically, the effect of 
fund herding behavior of countering optimistic market sentiment on fund performance. Also, researchers may employ the Structural Equation approach to examine the mediating role of institutional investor herding in the causal relationship between investor sentiment and stock returns. Such investigations will help corroborate the beneficial role of fund herding in speeding the price adjustment, as Wermers (1999) suggests, in the presence of mispricing resulting from investor sentiment.

This study proceeds in four sections. The next section discusses the estimation processes of fund herding and investor sentiment, the test methods and the variables. Section 3 describes the sample and data collection. Section 4 reports the empirical results. Finally, Section 5 summarizes the main conclusions.

\section{Methods}

\subsection{Trinomial-distribution herding measure}

To measure fund herding in stock $i$ in month $t(\mathrm{HMi}, \mathrm{t})$, the present report follows the Lakonishok et al. (1992) method:

$$
H M i, t=|P i, t-E(P i, t)|-E|P i, t-E(P i, t)|,
$$

where,

$$
\begin{aligned}
& P \mathrm{i}, \mathrm{t}=\mathrm{B}_{\mathrm{i}, \mathrm{t}} /\left(\mathrm{B}_{\mathrm{i}, \mathrm{t}}+\mathrm{S}_{\mathrm{i}, \mathrm{t}}\right) \\
& E\left(P_{i, t}\right)=\frac{\sum_{i=1}^{n} B_{i, t}}{\sum_{i=1}^{n}\left(B_{i, t}+S_{i, t}\right)}
\end{aligned}
$$

$B_{i, t}\left(S_{i, t}\right)$ is the number of fund managers who buy (sell) stock $i$ in month $t$. Pi,t is the proportion of mutual funds buying stock $i$ in month $t$ relative to the total number of funds trading stock $i$ in month $t$. E (Pi,t) is the sample estimate of $P i, t$, the expected proportion of buyers for stock $i$ in month $t . E|P i, t-E(P i, t)|$ is an adjustment which controls for random variation around the expected proportion of buyers under the null hypothesis of no herding. $|P i, t-E(P i, t)|$ will be large if the trading of managers polarizes in the direction of either buying or selling. Averaging HM over all stock-months of interest can measure the extent to which any fund herds in a given stock-month.

To examine mutual funds' reaction to signals conveying upward or downward consensus, the study calculates conditional herding measures for stock-months that have a higher or lower proportion of buyers than the average stock in the same month as follows:

$$
\begin{aligned}
& B H M=H M i, t \mid P i, t>E[P i, t] \\
& S H M=H M i, t \mid P i, t<E[P i, t]
\end{aligned}
$$

This approach is useful in analyzing fund herding into stocks separately from herding out of stocks. With Equation (4) as an example, the buy-herding measure (BHM) is equal to $H M$ 
conditional on $P_{i, t}>E\left[P_{i, t}\right]$. If mutual funds tend to herd in their selling of stocks more frequently than in their buying of stocks, then the sell-herding measure (SHM) will be larger than the buy-herding measure (BHM).

Previous studies (e.g., Choe et al., 1999; Wermers, 1999) focus mostly on the binomial distribution of herding measure and consider only the buy and sell positions. Wylie (2005) claims that the accuracy of the Lakonishok et al.'s (1992) measure may be in question because the analysis rests on the assumption that all fund managers can short sell all stocks. However, the U.S. law technically neither forbids nor allows mutual funds to undertake short sales. As Wylie (2005) notes, Section 12(a) of the Investment Companies Act 1940 prohibits short sales by registered mutual funds in contravention of SEC rules, while the SEC issues no rules under Section 12(a). As a result, few U.S. mutual funds undertake any short selling. Wylie thereby argues that essentially herding could arise because of this invalid assumption. To avoid obtaining systematic herding estimate, the following tests apply Wylie's (2005) trinomial-distribution approach to measure fund manager herding, including buy, hold and sell positions.

\subsection{Investor sentiment measure: Factor analysis approach}

This study next conducts the principal component analysis to extract indicators explaining investor sentiment. We use an orthogonal transformation to convert 10 possibly correlated indicators of investor sentiment, which are taken from the literature, into a set of values of uncorrelated indicators. We then base on the factor analysis to calculate the corresponding factor score for every sentiment proxy. The composite sentiment measure is the sum of multiplying the transformed factor score (weighting) by each indicator's value. Table 1 summarizes the definition and the corresponding weighting for each proxy. These ten sentiment indicators can be classified into three groups, including individual stock sentiment indicator, overall market sentiment indicator, and fund sentiment indicator.

\subsubsection{Individual stock sentiment indicator}

a. Individual stock return (ISR): De Long et al. (1990) and De Bondt (1993) find that investors predict the trend of stock returns according to past stock returns, so that the continuity of forecastable stock returns arises. For example, when the return continues for a period of time, the bullish psychology will pervade the investors. Notwithstanding the bull quotation occurs for a period of time and investors believe that the overall market would revise the quotation in the short term, the investors' bullish psychology remains.

b. Individual stock trading volume (ISV): Baker and Stein (2004) suggest that the market liquidity, like spreads, depth, trading volume and turnover, carrying information about the market can serve as a sentiment indicator. The trading volume is used as one of the sentiment proxy accordingly.

\subsubsection{Overall market sentiment indicator}

a. S\&P500 index return (SP500R) and Russell 2000 index return (RU2000R): The reason for incorporating these two proxies is the same as the ISR.

b. S\&P500 index trading volume $(S P 500 V)$ : The reason for this proxy is the same as the ISV. 
c. S\&P500 index option put to call ratio (SP500PC): Brown and Cliff (2004) note that a higher (lower) put to call ratio indicates the pessimistic (optimistic) atmosphere getting stronger. The S\&P500 index option put to call ratio is included as a proxy of the market sentiment.

d. Initial public offering first-day returns (IPOR) and the number of offerings (IPON): Due to the information asymmetries between IPO managers and outside investors, IPO activity tends to occur during bullish periods. Following Brown and Cliff (2004) and Baker and Wurgler (2006), the report includes both the IPO first-day returns and the number of offerings.

e. NYSE share turnover (NYSET): NYSE share turnover is the ratio of reported share volume to average shares listed from the NYSE Fact Book. In a market with short-sales constraints, Baker and Stein (2004) indicate that irrational investors will only be active in the market when they are optimistic and high liquidity is, as a result, a symptom of overvaluation.

\subsubsection{Fund sentiment indicator}

Net purchases of mutual funds (NP): Brown and Cliff (2004) indicate that net purchases by mutual funds and foreign investors positively reflect the extent to which they are optimistic about the individual stock. NP is the difference between dollar purchases and dollar sales by fund managers in a given stock.

\begin{tabular}{|c|c|c|c|}
\hline & Indicator & Definition & Weighting \\
\hline \multirow{2}{*}{$\begin{array}{l}\text { Individual } \\
\text { stock } \\
\text { sentiment }\end{array}$} & Individual stock return (ISR) & $\log \left(P_{\mathrm{i}, \mathrm{t}}\right)-\log \left(\mathrm{P}_{\mathrm{i}, \mathrm{t}-1}\right)$ & 0.097 \\
\hline & $\begin{array}{l}\text { Individual stock trading } \\
\text { volume (ISV) }\end{array}$ & $\log \left(\mathrm{V}_{\mathrm{i}, \mathrm{t}}\right)-\log \left(\mathrm{V}_{\mathrm{i}, \mathrm{t}-\mathrm{1}}\right)$ & 0.073 \\
\hline \multirow{7}{*}{$\begin{array}{l}\text { Market } \\
\text { sentiment }\end{array}$} & S\&P500 index return (SP500R) & $\log \left(S_{t}\right)-\log \left(S P_{t-1}\right)$ & 0.055 \\
\hline & $\begin{array}{l}\text { Russell } 2000 \text { index return } \\
\text { (RU2000R) }\end{array}$ & $\log \left(R u_{t}\right)-\log \left(R u_{t-1}\right)$ & 0.089 \\
\hline & $\begin{array}{l}\text { S\&P500 index trading volume } \\
\text { (SP500V) }\end{array}$ & $\log \left(\mathrm{SPV}_{\mathrm{t}}\right)-\log \left(\mathrm{SPV}_{\mathrm{t}-1}\right)$ & 0.093 \\
\hline & $\begin{array}{l}\text { S\&P500 index option Put/Call } \\
\text { ratio variation (SP500PC) }\end{array}$ & $\begin{array}{l}\left(\text { Put }_{t} / \text { Call }_{t}\right)-\left(\text { Put }_{t-}\right. \\
\left.1 / \text { Call }_{\mathrm{t}-1}\right)\end{array}$ & 0.105 \\
\hline & $\begin{array}{l}\text { Initial public offering first-day } \\
\text { return (IPOR) }\end{array}$ & See Jay Ritter website & 0.152 \\
\hline & Number of offerings (IPON) & See Jay Ritter website & 0.146 \\
\hline & NYSE share turnover (NYSET) & Volume/shares listed & 0.116 \\
\hline $\begin{array}{l}\text { Mutual fund } \\
\text { managers } \\
\text { sentiment }\end{array}$ & $\begin{array}{l}\text { Net purchases of mutual funds } \\
(\mathrm{NP})\end{array}$ & $\mathrm{B}_{\mathrm{t}}-\mathrm{S}_{\mathrm{t}}$ & 0.074 \\
\hline
\end{tabular}

Table 1. Investor Sentiment Indicators

Note. $\mathrm{P}_{\mathrm{i}, t}$ is the closing price at the end of month $t$ for stock $i . \mathrm{V}_{\mathrm{i}, t}$ is the trading volume of stock $i$ in month $t$. SP $\mathrm{P}_{\mathrm{t}}$ is the closing price at the end of month $t$ for $\mathrm{S} \& \mathrm{P} 500$ index. $\mathrm{Ru}_{\mathrm{t}}$ is the closing price at the end of month $t$ for Russell 2000 index. SPV $\mathrm{t}_{\mathrm{t}}$ is the S\&P500 trading volume in month $t$. Call (Put $\left._{\mathrm{t}}\right)$ is the open interest of S\&P500 call (put) option in month $t$. NP is the difference between dollar purchases and dollar sales by funds in a given stock, where $\mathrm{B}_{\mathrm{t}}\left(\mathrm{S}_{\mathrm{t}}\right)$ is the dollar purchases (sales) by funds in stock $i$ in month $t$. The weighting for each sentiment indicator is the transformed factor score by principal component analysis. 


\subsection{The effect of sentiment on fund herding}

To gauge the effect of investor sentiment on fund herding, the report estimates the following regression equations:

$$
\begin{aligned}
& \mathrm{HM}_{\mathrm{i}, \mathrm{t}}=\mathrm{a}_{0}+\mathrm{a}_{1}{ }^{*} \mathrm{~S}_{\mathrm{i}, \mathrm{t}-1}+\mathrm{a}_{2}{ }^{*} \operatorname{RSTD}_{\mathrm{t}-1}+\mathrm{a}_{3}{ }^{*} \mathrm{CAP}_{\mathrm{i}, \mathrm{t}}+\mathrm{a}_{4}{ }^{*} \mathrm{TNUMBER}_{\mathrm{i}, \mathrm{t}}+\mathrm{a}_{5}{ }^{*} \mathrm{PR}_{\mathrm{t}}+\mathrm{a}_{6}{ }^{*} \mathrm{~PB}_{\mathrm{i}, \mathrm{t}-1}+\varepsilon_{\mathrm{i}, \mathrm{t}} \\
& \mathrm{BHM}_{\mathrm{i}, \mathrm{t}}=\mathrm{a}_{0}+\mathrm{a}_{1} * \mathrm{~S}_{\mathrm{i}, \mathrm{t}-1}+\mathrm{a}_{2}{ }^{*} \operatorname{RSTD}_{\mathrm{t}-1}+\mathrm{a}_{3}{ }^{*} \mathrm{CAP}_{\mathrm{i}, \mathrm{t}}+\mathrm{a}_{4}{ }^{*} \mathrm{TNUMBER}_{\mathrm{i}, \mathrm{t}}+\mathrm{a}_{5} * \mathrm{PR}_{\mathrm{t}}+\mathrm{a}_{6}{ }^{*} \mathrm{~PB}_{\mathrm{i}, \mathrm{t}-1}+\varepsilon_{\mathrm{i}, \mathrm{t}} \\
& \mathrm{SHM}_{\mathrm{i}, \mathrm{t}}=\mathrm{a}_{0}+\mathrm{a}_{1}{ }^{*} \mathrm{~S}_{\mathrm{i}, \mathrm{t}-1}+\mathrm{a}_{2}{ }^{*} \operatorname{RSTD}_{\mathrm{t}-1}+\mathrm{a}_{3}{ }^{*} \mathrm{CAP}_{\mathrm{i}, \mathrm{t}}+\mathrm{a}_{4}{ }^{*} \mathrm{TNUMBER}_{\mathrm{i}, \mathrm{t}}+\mathrm{a}_{5} * \mathrm{PR}_{\mathrm{t}}+\mathrm{a}_{6}{ }^{*} \mathrm{~PB}_{\mathrm{i}, \mathrm{t}-\mathrm{t}, \varepsilon_{\mathrm{i}, \mathrm{t}}}
\end{aligned}
$$

Here, $H M$ is the aggregate fund herding measure, $B H M$ is the buy-herding measure and $S H M$ is the sell-herding measure. The main dependent variable, $S_{i, t-1}$, is the composite sentiment index of stock $i$ in month $t-1$. To support the sentiment countering argument, $\mathrm{a}_{1}$ is expected to be positive.

As for control variables, RSTDt-1 is the standard deviation of fund returns in month $t-1$. Bikhchandani et al. (1992) state that herding may result from some fund managers following other leader funds in their trades. A larger return deviation among funds in previous period indicates managers sharing dissimilar information and implies a higher reputation risk for underperformed managers, giving mutual funds a greater incentive to herd. Therefore, $\mathrm{a}_{2}$ is expected to be positive. Lakonishok et al. (1992), Wermers (1999) and Choe et al. (1999) establish that managers herd more on small stocks. $C A P_{i, t}$ is defined as the capitalization of stock $i$ in month $t$, and the coefficient $\left(\alpha_{3}\right)$ is expected to be negative. Wermers (1999) and Wylie (2005) indicate a positive relation between the level of herding in a given stock and the number of funds trading that stock $\left(T N U M B E R_{i, t}\right)$. The coefficient of TNUMBER $\left(\mathrm{a}_{4}\right)$ is thus expected to be positive.

Wermers (1999) argues that fund may herd in response to sudden increases in cash inflow (mutual fund purchases) or cash outflows (mutual fund redemptions). The disproportional purchase (redemption) waves initiated by fund investors may force managers to increase (decrease) their stock holding simultaneously, and hence result in a buy (sell) herding. The net mutual fund redemption $\left(P R_{t}\right)$ is the ratio of mutual fund purchases minus mutual fund redemptions in month $t$ to fund assets. The coefficient $\left(\alpha_{5}\right)$ is expected to be positive (negative) when BHM (SHM) is the dependent variable of the regression equation. The ratio of market value to book equity at the beginning of the trading quarter for stock $i\left(P B_{i, t-1}\right)$ is used as a proxy for growth opportunity. The coefficient $\left(a_{6}\right)$ is expected to be positive as Wermers (1999) shows that higher levels of herding by growth-oriented funds are consistent with growth fund possessing less precise information about the true value of their stockholdings (mainly growth stocks). Finally, an industry dummy (equal to one for stocks of high-tech firms, zero otherwise) and four yearly dummies (2001 as the base year) are included in Equations (6) through (8) to control the possible industry and macroeconomic effects on fund herding behavior.

\section{Sample and data collection}

The sample contains 770 U.S. mutual funds' trading records on 527 stocks from 2003 to 2007, after excluding observations with incomplete data to estimate fund herding. Taking each monthly change in a stock as a separate trading, the total stock-month observations amount 
to 31,093 , including 17,095 buy-herding and 13,998 sell-herding observations. Instead of using quarterly fund trading data, this study analyzes the fund herding behavior with monthly data to reduce the impact of intra-period round-trip transactions on the results.

Monthly data on portfolio holdings of the U.S. mutual funds are collected from the CRSP Mutual Fund Database. These data include periodic share holdings of equities for each fund at the end of each month. Individual stock price, trading volume and capitalization are obtained from the CRSP as well. S\&P500 index return, S\&P500 trading volume, S\&P500 index option call/put open interest, NYSE share turnover and Russell 2000 index return are compiled from the Datastream. The number of IPOs and the average first-day returns of IPOs are available at the Jay Ritter website (http:// bear.cba.ufl.edu/ritter).

\section{Empirical results}

\subsection{Descriptive statistics and correlations between selected variables}

Table 2 provides the descriptive statistics of the three herding measures, ten sentiment-related indicators and selected control variables in the regression analyses. The mean herding measures are $1.779 \%(H M), 2.164 \%$ (BHM) and $1.308 \%$ (SHM), respectively. The medians of the three herding measures are even smaller. These statistics indicate that fund managers seem not to herd much, in line with the findings of Lakonishok et al. (1992) and werners (1999).

\begin{tabular}{cccccccc}
\hline Variable & Mean & Std. Dev. & Min & Q1 & Median & Q3 & Max \\
\hline HM (\%) & 1.779 & 5.606 & -16.232 & -1.612 & 0.287 & 3.798 & 97.664 \\
BHM (\%) & 2.164 & 5.913 & -16.648 & -1.577 & 0.548 & 4.335 & 77.654 \\
SHM (\%) & 1.308 & 5.267 & -16.233 & -1.686 & 0.196 & 3.280 & 96.685 \\
ISR & 0.007 & 0.040 & -0.614 & -0.013 & 0.009 & 0.031 & 0.375 \\
ISV & 0.046 & 0.055 & -0.085 & -0.038 & -0.006 & 0.040 & 1.142 \\
SP500R & 0.006 & 0.070 & -0.015 & -0.003 & 0.005 & 0.007 & 0.025 \\
SP500V & 0.041 & 0.049 & -0.079 & -0.041 & 0.018 & 0.058 & 0.101 \\
RU2000R & 0.008 & 0.042 & -0.068 & -0.022 & 0.021 & 0.044 & 0.089 \\
SP500PC & -0.012 & 0.076 & -0.147 & -0.034 & -0.025 & 0.030 & 0.139 \\
IPOR & 0.122 & 0.013 & 0.102 & 0.121 & 0.122 & 0.123 & 0.140 \\
IPON & 142.600 & 45.026 & 63 & 156 & 159 & 161 & 174 \\
NYSET & 0.432 & 0.421 & 0.363 & 0.621 & 0.625 & 0.632 & 0.648 \\
NP & 267,447 & $33,103,284$ & $-1.079 E 9$ & $-1,970,434$ & 126,690 & $2,391,904$ & $601,787,572$ \\
S $_{\mathrm{t}-1}$ & 54.961 & 13.164 & 33.969 & 47.003 & 56.552 & 60.168 & 69.347 \\
RSTD $_{\mathrm{t}-1}$ & 0.022 & 0.013 & 0.015 & 0.016 & 0.022 & 0.028 & 0.045 \\
CAP $_{\mathrm{t}}$ & $6,550,706$ & $21,769,725$ & 42,230 & 557,247 & $1,417,585$ & $4,107,318$ & $317,133,094$ \\
TNUMBER $_{\mathrm{t}}$ & 120.166 & 121.391 & 2 & 56 & 87 & 146 & 651 \\
PR $_{\mathrm{t}}$ & 0.004 & 0.004 & -0.015 & 0.002 & 0.004 & 0.009 & 0.017 \\
PB $_{\mathrm{t}-1}$ & 7.970 & 213.206 & -136.187 & 1.594 & 2.621 & 3.966 & 13372.830 \\
\hline
\end{tabular}

Table 2. Descriptive Statistics of Herding Measures and Selected Variables

Note. The sample contains 770 U.S. mutual funds' holding records on 527 stocks from 2001 to 2005 , including 31,093 (17,095 buy-herding and 13,998 sell-herding) observations. HM is the aggregate herding measure. BHM is the buy-herding measure. SHM is the sell-herding measure. ISR is the individual stock return. ISV is the change of the logarithm of individual stock trading volume. SP500R is the S\&P500 index return. SP500V is the change of the logarithm of S\&P500 index trading volume. 
RU2000R is the Russell 2000 index return. SP500PC is the S\&P500 index option Put/Call ratio variation. IPOR is the mean first-day return of IPOs. IPON is the number of IPOs. NYSET is the NYSE share turnover. NP is the difference between dollar purchases and dollar sales by fund managers in a given stock. $S$ is the composite sentiment measure. RSTD is the standard deviation of fund return. CAP is the capitalization of a given stock. TNUMBER is the number of funds trading a given stock. PR is the ratio of mutual fund purchases minus mutual fund redemptions in a given month to net assets of the fund. $\mathrm{PB}$ is the ratio of market value to book equity at the beginning of the trading quarter.

Table 3 presents Spearman (upper-triangle) and Pearson (lower-triangle) correlation coefficients between selected variables. In the Spearman measure, the correlation between the composite sentiment measure $\left(S_{t-1}\right)$ and the aggregate herding $\left(H M_{t}\right)$ is significantly positive (0.032). Likewise, the correlation between $S_{t-1}$ and the sell-herding $\left(S H M_{t}\right)$ is also significantly positive (0.039). However, the correlation between $S_{t-1}$ and the buy-herding $\left(B H M_{t}\right)$ is not significantly different from zero (0.013). The bivariate correlation evidence shows that investor sentiment does affect fund herding, especially on the sell-side. Although some of the figures are insignificant, the correlation coefficients between control variables and the herding measures correspond mostly with the predicted signs. The results in the Pearson measure are qualitatively similar to the findings in the Spearman measure.

\begin{tabular}{|c|c|c|c|c|c|c|c|}
\hline \multicolumn{8}{|c|}{ Panel A: Herding measure (HM) } \\
\hline & $\mathrm{HM}_{\mathrm{t}}$ & $S_{t-1}$ & RSTD $_{\mathrm{t}-1}$ & $\mathrm{CAP}_{\mathrm{t}}$ & TNUMBER $_{\mathrm{t}}$ & $\mathrm{PR}_{\mathrm{t}}$ & $\mathrm{PB}_{\mathrm{t}-1}$ \\
\hline $\mathrm{HM}_{\mathrm{t}}$ & & $0.032^{* * *}$ & $0.066^{* * *}$ & 0.005 & 0.012 & 0.010 & 0.019 \\
\hline $\mathrm{S}_{\mathrm{t}-1}$ & $0.031^{* *}$ & & $-0.304^{* * *}$ & $0.035^{* * *}$ & $0.043^{* * *}$ & $0.160 * * *$ & 0.019 \\
\hline $\operatorname{RSTD}_{\mathrm{t}-1}$ & $0.066^{* * *}$ & $-0.414^{* * *}$ & & -0.007 & $-0.077^{* * *}$ & $0.092^{* * *}$ & -0.013 \\
\hline $\mathrm{CAP}_{\mathrm{t}}$ & -0.014 & $0.028^{\star *}$ & -0.001 & & $0.551^{* * *}$ & $0.030^{* * *}$ & 0.014 \\
\hline TNUMBER $_{t}$ & $0.026 * *$ & $0.046^{* * *}$ & $-0.058^{* * *}$ & $0.433^{* * *}$ & & -0.008 & 0.007 \\
\hline $\mathrm{PR}_{\mathrm{t}}$ & 0.016 & $0.170^{* * *}$ & $0.134^{* * *}$ & $0.022^{*}$ & $-0.027 * *$ & & 0.006 \\
\hline $\mathrm{PB}_{\mathrm{t}-1}$ & 0.005 & 0.009 & -0.016 & -0.005 & -0.014 & -0.008 & \\
\hline \multicolumn{8}{|c|}{ Panel B: Buy-herding measure (BHM) } \\
\hline & $\mathrm{BHM}_{\mathrm{t}}$ & $\mathrm{S}_{\mathrm{t}-1}$ & RSTD $_{\mathrm{t}-1}$ & $\mathrm{CAP}_{\mathrm{t}}$ & TNUMBER $_{\mathrm{t}}$ & $\mathrm{PR}_{\mathrm{t}}$ & $P B_{t-1}$ \\
\hline $\mathrm{BHM}_{\mathrm{t}}$ & & 0.013 & $0.032^{* * *}$ & $-0.065^{* * *}$ & $0.046^{* * *}$ & $0.034^{* * *}$ & -0.007 \\
\hline $\mathrm{S}_{\mathrm{t}-1}$ & -0.013 & & $-0.285^{* * *}$ & $0.028^{* *}$ & 0.014 & $0.226^{* * *}$ & 0.019 \\
\hline $\operatorname{RSTD}_{\mathrm{t}-1}$ & $0.027^{* *}$ & $-0.411^{* * *}$ & & $0.037^{* * *}$ & 0.019 & $-0.188^{* * *}$ & 0.011 \\
\hline $\mathrm{CAP}_{\mathrm{t}}$ & $-0.034^{* *}$ & 0.011 & $0.086^{* * *}$ & & $0.474^{* * *}$ & $0.110^{* * *}$ & 0.005 \\
\hline TNUMBER $_{t}$ & $0.073^{* * *}$ & 0.016 & $0.052^{* * *}$ & $0.412^{* * *}$ & & $0.061^{* * *}$ & -0.004 \\
\hline $\mathrm{PR}_{\mathrm{t}}$ & $0.050^{* * *}$ & $0.198^{* * *}$ & $-0.021^{*}$ & $0.094^{* * *}$ & $0.081^{* * *}$ & & 0.008 \\
\hline $\mathrm{PB}_{\mathrm{t}-1}$ & 0.005 & 0.013 & $-0.024^{*}$ & -0.005 & -0.017 & -0.008 & \\
\hline \multicolumn{8}{|c|}{ Panel C: Sell-herding measure (SHM) } \\
\hline & $\mathrm{SHM}_{\mathrm{t}}$ & $\mathrm{S}_{\mathrm{t}-1}$ & $\mathrm{RSTD}_{\mathrm{t}-1}$ & $\mathrm{CAP}_{\mathrm{t}}$ & TNUMBER $_{\mathrm{t}}$ & $\mathrm{PR}_{\mathrm{t}}$ & $\mathrm{PB}_{\mathrm{t}-1}$ \\
\hline $\mathrm{SHM}_{\mathrm{t}}$ & & $0.039 * * *$ & $0.123^{* * *}$ & $0.113^{* * *}$ & $0.121^{* * *}$ & $-0.066^{* * *}$ & $0.026^{*}$ \\
\hline$S_{\mathrm{t}-1}$ & $0.026^{* *}$ & & $-0.300 * * *$ & $0.067^{* * *}$ & $0.075^{* * *}$ & $0.117^{* * *}$ & 0.008 \\
\hline RSTD $_{\mathrm{t}-1}$ & $0.101^{* * *}$ & $-0.443^{* * *}$ & & $-0.083^{* * *}$ & $-0.170^{* * *}$ & $0.156^{* * *}$ & -0.022 \\
\hline $\mathrm{CAP}_{\mathrm{t}}$ & $0.049^{* * *}$ & $0.037^{* * *}$ & $-0.073^{* * *}$ & & $0.522 * * *$ & $-0.078 * * *$ & 0.017 \\
\hline TNUMBER $_{\mathrm{t}}$ & $0.039^{* * *}$ & $0.086^{* * *}$ & $-0.150^{* * *}$ & $0.455^{* * *}$ & & $-0.114^{* * *}$ & 0.010 \\
\hline $\mathrm{PR}_{\mathrm{t}}$ & $-0.098^{* * *}$ & $0.126^{* * *}$ & $0.242^{* * *}$ & $-0.060^{* * *}$ & $-0.104^{* * *}$ & & 0.007 \\
\hline $\mathrm{PB}_{\mathrm{t}-1}$ & 0.016 & -0.001 & 0.003 & -0.002 & -0.007 & -0.016 & \\
\hline
\end{tabular}

Table 3. Correlation Coefficients between Regression Variables 
Note. The Spearman (Pearson) correlation coefficients are reported at the upper-triangle (lowertriangle). The sample contains 770 U.S. mutual funds' holding records on 527 stocks from 2001 to 2005 , including 31,093 (17,095 buy-herding and 13,998 sell-herding) stock-month observations. HM is the aggregate herding measure. BHM is the buy-herding measure. SHM is the sell-herding measure. S is the composite sentiment measure. RSTD is the standard deviation of fund return. CAP is the capitalization of a given stock. TNUMBER is the number of funds trading a given stock. PR is the ratio of mutual fund purchases minus mutual fund redemption in a given month to net assets of the fund. PB is the ratio of market value to book equity at the beginning of the trading quarter. ${ }^{* * *},{ }^{* *}$ and * indicate significant at the $0.01,0.05$ and 0.10 level, respectively.

\subsection{Herding comparisons between high and low sentiment sub-samples}

The bivariate correlation results in Table 3 indicate that $S_{t-1}$ relates positively with $H M$ and $S H M$. Fund managers show a tendency to herd in trading stocks with high investor sentiment, especially on the sell-side. To further support this view, Table 4 presents univariate comparisons of herding between high and low $S_{t-1}$ sub-samples. High (low) $S_{t-1}$ sub-sample refers to observations with $S_{t-1}$ greater (less) than the median $S_{t-1}$ of the full sample. Relative to low $S_{t-1}$ stocks, stocks with high $S_{t-1}$ also have higher mean and median $H M(t=5.086$ and $Z=3.475$ respectively). Similarly, both the mean and median $S H M$ for high $S_{t-1}$ subsample are significantly higher than the figures for low $S_{t-1}$ subsample ( $t=5.755$ and $Z=3.969$ respectively). However, neither the mean nor median of $B H M$ for high $S_{t-1}$ subgroup is significantly different from that of low $S_{t-1}$ subgroup ( $t=1.419$ and $Z=1.160$ respectively). By and large, the observed fund herding behavior in high sentiment stocks mostly comes from selling herding rather than from buying herding. Consequently, Table 4 provides evidence consistent with the correlation coefficient findings in Table 3, suggesting that fund herds form more often on the sell-side than on the buy-side in stocks with high past investor sentiment.

\begin{tabular}{ccccc}
\hline & & HM & BHM & SHM \\
\hline High St-1 & Mean & 0.017 & 0.018 & 0.013 \\
& Std Dev. & 0.053 & 0.066 & 0.052 \\
& Median & 0.004 & 0.004 & 0.003 \\
\hline Low St-1 & Mean & 0.014 & 0.017 & 0.010 \\
& Std Dev. & 0.051 & 0.058 & 0.039 \\
& Median & 0.002 & 0.003 & 0.001 \\
\hline t value for the difference & $5.086(<.001)^{* * *}$ & $1.419(0.156)$ & $5.755(<.001)^{* * *}$ \\
Wilcoxon Z the difference & $3.475(<.001)^{* * *}$ & $1.160(0.246)$ & $3.969(<.001)^{* * *}$ \\
\hline
\end{tabular}

Table 4. Herding Comparisons between High and Low Sentiment Sub-samples

Note. The sample contains 770 U.S. mutual funds' holding records on 527 stocks from 2001 to 2005 , including 31,093 (17,095 buy-herding and 13,998 sell-herding) stock-month observations. $\mathrm{S}_{\mathrm{t}-1}$ is the sentiment index in month $t-1$. High (low) $\mathrm{S}_{\mathrm{t}-1}$ sub-sample refers to observations with $\mathrm{S}_{\mathrm{t}-1}$ greater (less) than the median $S_{t-1}$ of the full sample. HM is the aggregate herding measure. BHM is the buy-herding measure. SHM is the sell-herding measure. The test statistics are heteroskedastic $t$-tests of equal means and non-parametric Wilcoxon Z-values of equal medians comparing high sentiment sub-sample with low sentiment sub-sample. Figures in parentheses are $p$ values. ${ }^{* * *}$ indicates significant at the 0.01 level.

\subsection{The effect of prior sentiment on fund herding}

Table 5 reports the regression results for different fund herding measures: aggregate herding $(H M)$, buy-herding $(B H M)$ and sell-herding $(S H M)$. The $t$-statistics in Table 5 are 
based on White's heteroskedasticity consistent estimator for standard errors. The VIFs for all independent variables are smaller than 3, indicating that collinearity does not pose an issue in model estimation (Kennedy, 2003).

\begin{tabular}{|c|c|c|c|c|}
\hline \multicolumn{2}{|l|}{ Expected Sign } & \multicolumn{3}{|l|}{ Dependent Variable } \\
\hline & & \multirow{2}{*}{$\begin{array}{l}\mathrm{HM} \\
\text { Estimated Coefficient }\end{array}$} & \multirow{2}{*}{$\begin{array}{l}\text { BHM } \\
\text { Estimated Coefficient }\end{array}$} & \multirow{2}{*}{$\begin{array}{l}\text { SHM } \\
\text { Estimated Coefficient }\end{array}$} \\
\hline & & & & \\
\hline \multirow{2}{*}{\multicolumn{2}{|c|}{ Intercept }} & 0.0865 & 0.1514 & 0.1025 \\
\hline & & $(0.9307)$ & $(1.1844)$ & $(1.0626)$ \\
\hline \multirow[t]{3}{*}{ St-1 } & + & 0.0003 & 0.0002 & 0.0003 \\
\hline & & $(2.2866)^{* *}$ & $(1.1715)$ & $(1.9429)^{*}$ \\
\hline & & [1.4640] & [1.3662] & [1.3817] \\
\hline \multirow[t]{3}{*}{ RSTDt-1 } & + & 0.2461 & 0.1707 & 0.4538 \\
\hline & & $(6.5192)^{\star * *}$ & $(1.8334)^{*}$ & $(7.2789)^{* * *}$ \\
\hline & & [1.2206] & [1.2188] & [1.4552] \\
\hline \multirow[t]{3}{*}{ CAPt } & - & $-2.4660 \mathrm{E}-10$ & $-3.6311 \mathrm{E}-10$ & $-7.2224 \mathrm{E}-11$ \\
\hline & & $(-5.8024)^{\star * *}$ & $(-6.6908)^{\star * *}$ & $(-4.4602)^{* * *}$ \\
\hline & & [2.5679] & [2.4828] & {$[2.5714]$} \\
\hline \multirow[t]{3}{*}{ TNUMBERt } & + & $6.7002 \mathrm{E}-5$ & $8.7430 \mathrm{E}-5$ & $3.2909 \mathrm{E}-5$ \\
\hline & & $(6.8879)^{\star * *}$ & $(3.3417)^{* * *}$ & $(2.8771)^{\star * *}$ \\
\hline & & [2.3489] & [2.1701] & [2.4336] \\
\hline \multirow[t]{3}{*}{ PRt } & $+/+/-$ & 0.0322 & 0.0445 & -0.0103 \\
\hline & & $(0.9796)$ & $(3.8710)^{* * *}$ & $(-2.0621)^{* *}$ \\
\hline & & [1.1518] & [1.1440] & {$[1.2581]$} \\
\hline \multirow[t]{3}{*}{ PBt-1 } & + & $1.6133 \mathrm{E}-6$ & $8.8284 \mathrm{E}-7$ & $2.7620 \mathrm{E}-5$ \\
\hline & & $(0.3765)$ & $(0.1917)$ & $(0.9920)$ \\
\hline & & [1.0104] & [1.0399] & [1.0530] \\
\hline $\mathrm{N}$ & & 31093 & 17095 & 13998 \\
\hline Adj. R-sq & & 0.0240 & 0.0129 & 0.0218 \\
\hline Prob. $\left(F>F^{*}\right)$ & & $<0.0001$ & $<0.0001$ & $<0.0001$ \\
\hline
\end{tabular}

Table 5. The Effect of Investor Sentiment on Fund Herding

Note. The sample is the 770 U.S. mutual funds' holding records on 527 stocks from 2001 to 2005 , including 31,093 (17,095 buy-herding and 13,998 sell-herding) observations. HM is the aggregate herding measure. BHM is the buy-herding measure. SHM is the sell-herding measure. $\mathrm{S}$ is the composite sentiment measure. RSTD is the standard deviation of fund return. CAP is the capitalization of a given stock. TNUMBER is the number of funds trade in a given stock. PR is the dollar amount of purchase minus the dollar amount of redemption by mutual funds in a given month, scaled by net assets of the fund. PB is the ratio of market value to book equity at the beginning of the trading quarter. An industry dummy (equal to one for stocks of high-tech firms, zero otherwise) and four yearly dummies (2001 as the base year) are included in each model to control the possible industry and macroeconomic effects on herding behavior (not shown in the table). The $t$-statistics are based on White's heteroskedasticity consistent estimator for standard errors. $t$ values are in ( ); VIFs are in [ ]; ***, ** and * indicate significant at the $0.01,0.05$ and 0.10 level, respectively. 
For factors affecting $H M$, the concern of this study is the composite sentiment measure $\left(S_{t-1}\right)$. $S_{t-1}$ has a positive and significant coefficient $(t=2.2866)$, which is consistent with the notion that funds trade in herd more frequently on stocks with prior high sentiment. $S_{t-1}$ positively relates to SHM ( $t=1.9429)$ but insignificantly relates to BHM $(t=1.1715)$, revealing that the positive effect of $S_{t-1}$ on $H M$ mostly comes from the sell-side herding rather than the buyside herding. These findings indicate that fund managers share an aversion to stocks with high past optimistic sentiment. Overall, the evidence again corroborates the results in Table 3 and Table 4 and provides stronger support for the sentiment countering argument that institutional investors have an inclination to counter optimistic investor sentiment. Also, the evidence implicates the use of negative-feedback strategies by mutual funds as an important source of herding.

Of the control variables, the deviation of fund returns in previous month (RSTDt-1) has a positive effect on all three herding measures ( $t=6.5192,1.8334$ and 7.2789 respectively), consistent with Bikhchandani et al.'s (1992) reputational risk argument. The stock capitalization $(C A P t)$ negatively relates with all three herding measures $(t=-5.8024,-6.6908$ and -4.4602 respectively), showing that herding is more pronounced in small stocks. This result is consistent with the various herding theories where fund managers may receive lower precision information from these firms and are more likely to ignore this information if consensus opinion is different, or fund managers may share an aversion to holding small stocks because these stocks are less liquid (Lakonishok et al., 1992; Wermers, 1999; Choe et al., 1999). The positive effect of the number of funds trading a stock (TNUMBER T $_{\mathrm{t}}$ on all three herding measures $(t=6.8879,3.3417$ and 2.8771 respectively) is consistent with the findings of Wermers (1999) and Wylie (2005). The net mutual fund redemption $\left(P R_{t}\right)$ positively correlates with BHM $(t=3.8710)$ and negatively correlates with SHM $(t=-2.0621)$, similar to the findings in Edelen (1999) and Gallagher and Jarnecic (2004). Finally, the coefficient of market-to-book ratio is not significant in all three models, suggesting that the growth orientation of stocks does not play a role in explaining the level of fund managers herding.

\subsection{Sensitivity tests}

To assess the robustness of the results, the study includes four sensitivity tests : (1) reestimating Table 4 and Table 5 for sub-periods "2001-2002" (a bear market) and "2003-2005" (a bull market) separately; (2) excluding 5\% of upper outliers to alleviate the effect of extreme BHM and SHM and this process reduces the sample size to 16240 buy-herding and 13298 sellherding observations; (3) replacing the trinomial-distribution herding measure with the popular binomial- distribution herding measure (Lakonishok et al., 1992); and (4) replacing the investor sentiment measure (St-1) in Table 4 and Table 5 with a two-period lag measure (St-2). The results (not reported) of these tests are qualitatively similar to those reported.

\section{Conclusions}

This paper assesses the relation between investor sentiment and the extent to which fund managers herd in their trades of stocks. The study applies the Lakonishok et al.'s (1992) measure and Wylie's (2005) trinomial-distribution approach to gauge fund manager herding, and uses the principal component analysis as the means of extracting the 
composite unobserved sentiment measure from ten market weather indicators that can be categorized into three groups: individual stock sentiment indicator, overall market sentiment indicator, and fund sentiment indicator.

The empirical results suggest that investor sentiment plays a significant role in explaining mutual fund herding cross-sectionally, especially on the sell-side. Fund managers show a stronger tendency to herd out of stocks with high prior investor sentiment than to herd into stocks with high prior sentiment. In other words, managers herd sell because, at least in part, they observe and counteract the optimistic sentiment. This finding is consistent with the funds sharing an aversion to stocks that have previously demonstrated high optimistic sentiment, supporting the sentiment countering hypothesis. The results also provide support for the informational cascade theory where managers herd because of analyzing the same sentiment-related indicators.

\section{References}

Baker, M., Stein, J.C., 2004. Market liquidity as a sentiment indicator. Journal of Financial Markets 7(3), 271-299.

Baker, M., Wurgler, J., 2006. Investor sentiment and the cross-section of stock returns. Journal of Finance 61(4), 1645-1680.

Bala, V., Goyal, S., 1998. Learning from neighbors. Review of Economic Studies 65(3), 595621.

Banerjee, A., 1992. A simple model of herd behavior. Quarterly Journal of Economics 107(3), 797-817.

Barberis, N.C., Shleifer, A., 2003. Style investing. Journal of Financial Economics 68(2), 161199.

Bikhchandani, S., Hirshleifer, D., Welch, I., 1992. A theory of fads, fashion, custom, and cultural change as informational cascades. Journal of Political Economy 100(5), $992-$ 1026.

Block, S.B., French, D.W., Maberly, E.D., 2000. The pattern of intraday portfolio management decisions: a case study of intraday security return patterns. Journal of Business Research 50(3), 321-326.

Brandenburger, A., Polak, B., 1996. When managers cover their posteriors: Making the decisions the market wants to see. Rand Journal of Economics 27(3), 523-541.

Brown, G.W., Cliff, M.T., 2004. Investor sentiment and the near-term stock market. Journal of Empirical Finance 11(1), 1-27.

Choe, H., Kho, B.C., Stulz, R.M., 1999. Do foreign investor destabilize stock markets? The Korean experience in 1997. Journal of Financial Economics 54(2), 227-264.

De Bondt, W.F., 1993. Betting on trends: Intuitive forecasts of financial risk and return. International Journal of Forecasting 9(3), 355-371.

De Long, J.B., Shlerter, A., Summers, L.H., Waldmann, R.J., 1990. Noise trader risk in financial markets. Journal of Political Economy 98(4), 703-738.

Del Guercio, D., 1996. The distorting effect of the prudent-man laws on institutional equity investments. Journal of Financial Economics 40(1), 31-62.

Edelen, R.M., 1999. Investor flows and the assessed performance of open end fund managers. Journal of Financial Economics 53(3), 439-466. 
Falkenstein, E.G., 1996. Preferences for stock characteristics as revealed by mutual fund portfolio holdings. Journal of Finance 51(1), 111-135.

Fisher, K.L., Statman, M., 2000. Investor sentiment and stock returns. Financial Analysts Journal 56(2), 16-23.

Froot, K.A., Scharfstein, D.S., Stein, J.C., 1992. Herd on the street: Informational inefficiencies in a market with short-term speculation. Journal of Finance 47(4), 1461-1484.

Fung, W., Hsieh, D.A., 1999. A primer on hedge funds. Journal of Empirical Finance 6(3), 309-331.

Gallagher, D.R., Jarnecic, E., 2004. International equity funds, performance, and investor flows: Australian evidence. Journal of Multinational Financial Management 14(1), 81-95.

Gompers, P., Metrick, A., 2001. How are large institutions different from other investors? Quarterly Journal of Economics 16(1), 229-259.

Grinblatt, M., Titman, S., Wermers, R., 1995. Momentum investment strategies, portfolio performance, and herding: A study of mutual fund behavior. American Economic Review 85(5), 1088-1105.

Hirschleifer, D., Subrahmanyam, A., Titman, S., 1994. Security analysis and trading patterns: When some investors receive information before others. Journal of Finance 49(5), 1665-1698.

Jegadeesh, N., Titman, S., 1993. Returns to buying winners and selling losers: Implications for stock market efficiency. Journal of Finance 48(1), 65-91.

Kennedy, P., 2003. A guide to econometrics. Cambridge, MA: MIT Press.

Klemkosky, R.C., 1977. The impact and efficiency of institutional net trading imbalances. Journal of Finance 32(1), 79-86.

Kyrolainen, P., Perttunen, J., 2003. Investors' activity and trading behavior. Working paper, University of Oulu, Finland.

Lakonishok, J., Shleifer, A., Vishny, R.W., 1992. The impact of institutional trading on stock prices. Journal of Financial Economics 32(1), 23-43.

Lee, C., Shleifer, A., Thaler, R., 1991. Investor sentiment and the closed-end fund puzzle. Journal of Finance 46(1), 75-109.

Neal, R., Wheatley, S.M., 1998. Do measures of investor sentiment predict returns? Journal of Financial and Quantitative Analysis 33(4), 523-548.

Nofsinger, J.R., Sias, R.W., 1999. Herding and feedback trading by institutional and individual investors. Journal of Finance 54(6), 2263-2295.

Payne, T.H., Prather, L., Bertin, W., 1999. Value creation and determinants of equity fund performance. Journal of Business Research 45(1), 69-74.

Pound, J., Shiller, R.J., 1989. Survey evidence on diffusion of interest and information among investors. Journal of Economic Behavior and Organization 12(1), 47.67.

Prendergast, C., 1993. A theory of yes men. American Economic Review 83(4), 757-770.

Scharfstein, D., Stein, J., 1990. Herd behavior and investment. American Economic Review 80(3), 465-479.

Shleifer, A., 2000. Inefficient markets: An introduction to behavioral finance. Oxford University Press, Oxford.

Trueman, B., 1994. Analyst forecasts and herding behavior. Review of Financial Studies 7(1), 97-124. 
Walter, A., Weber, F.M., 2006. Herding in the German mutual fund industry. European Financial Management 12(3), 375-406.

Wermers, R., 1997. Momentum investment strategies of mutual funds, performance persistence, and survivorship bias. Working paper, University of Colorado.

Wermers, R., 1999. Mutual fund herding and the impact on stock price. Journal of Finance 54(2), 581-622.

White, H., 1980. A heteroskedasticity-consistent covariance matrix estimator and a direct test for heteroskedasticity. Econometrica 48(1), 817-838.

Wylie, S., 2005. Fund manager herding: a test of the accuracy of empirical results using U.K. data. Journal of Business 78(1), 381-403.

Zwiebel, J., 1995. Corporate conservatism and relative compensation. Journal of Political Economy 103(1), 1-25. 


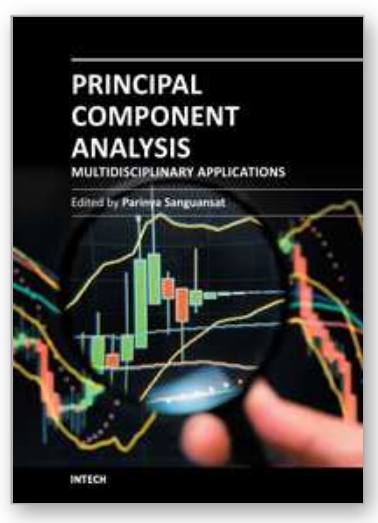

\author{
Principal Component Analysis - Multidisciplinary Applications \\ Edited by Dr. Parinya Sanguansat
}

ISBN 978-953-51-0129-1

Hard cover, 212 pages

Publisher InTech

Published online 29, February, 2012

Published in print edition February, 2012

This book is aimed at raising awareness of researchers, scientists and engineers on the benefits of Principal Component Analysis (PCA) in data analysis. In this book, the reader will find the applications of PCA in fields such as taxonomy, biology, pharmacy,finance, agriculture, ecology, health and architecture.

\title{
How to reference
}

In order to correctly reference this scholarly work, feel free to copy and paste the following:

Tsai-Ling Liao, Chih-Jen Huang and Chieh-Yuan Wu (2012). Empirical Study: Do Fund Managers Herd to Counter Investor Sentiment?, Principal Component Analysis - Multidisciplinary Applications, Dr. Parinya Sanguansat (Ed.), ISBN: 978-953-51-0129-1, InTech, Available from:

http://www.intechopen.com/books/principal-component-analysis-multidisciplinary-applications/empirical-studydo-fund-managers-herd-to-counter-investor-sentiment-

\section{INTECH}

open science | open minds

\author{
InTech Europe \\ University Campus STeP Ri \\ Slavka Krautzeka 83/A \\ 51000 Rijeka, Croatia \\ Phone: +385 (51) 770447 \\ Fax: +385 (51) 686166 \\ www.intechopen.com
}

\author{
InTech China \\ Unit 405, Office Block, Hotel Equatorial Shanghai \\ No.65, Yan An Road (West), Shanghai, 200040, China \\ 中国上海市延安西路65号上海国际贵都大饭店办公楼405单元 \\ Phone: +86-21-62489820 \\ Fax: +86-21-62489821
}


(C) 2012 The Author(s). Licensee IntechOpen. This is an open access article distributed under the terms of the Creative Commons Attribution 3.0 License, which permits unrestricted use, distribution, and reproduction in any medium, provided the original work is properly cited. 